\title{
Semantic Changes of Words in Albanian Language
}

\author{
Adelina SULA, PhD Cand. \\ Faculty of History and Philology, University of Tirana, \\ adelinasula@gmail.com
}

\begin{abstract}
The language has changed over the years due to social, cultural, economic and scientific developments. Changes are not only in new words, but also in the same words with different meanings. These words are explained differently in dictionaries. In the language of politics, emphasis is a fruitful discourse strategy. Persuasion and convincing are key strategies of politics. In this paper, we study these words, reasons of changes. This study is based in the dictionaries of Albanian language. Comparing the dictionaries of 1980 to 2006 word by word, we highlight those words with different explanation.
\end{abstract}

Keywords: revolution, ideology, politic language, semantic changes, etc.

\section{Introduction}

The dictionary includes all the vocabulary of a language as synchronic and diachronic aspect. Each historical period leaves its traces in the dictionary, especially when there are great political, economic, cultural changes.

The tradition of the Albanian language dictionaries starts from 1960. The first scientific attempt to compile a dictionary of Albanian language was made by K. Kristoforidhi, "Dictionary of the Albanian language". This tradition is inherited by other lexicographers.

Language is a tool, through which people communicate with one another, exchange thoughts and understand each other. Being a social mean of communication, language is also a tool of war and society development. The key requirement is to determine the most suitable language elements to meet the needs of our society, to facilitate the spread of development of culture and science.

In this paper we will discuss the semantic changes, answered questions as why the meanings of words have been changed and which registers are more affected.

\section{Literature review}

The problem of explaining the words in today positions is an ideological problem. In the explanation of the words the compilers express how they understand the concepts that explain, the attitude towards these notions. Regarding the impact of society on the Albanian language, the degree of culture and linguistic consciousness of its holders have an important role. It is known that language is in the service of society and has no class character.

Before 90s the authors explain vocabulary words from ideological positions of the bourgeoisie. Lexicon has ideological character. And for this reason, ideological problem in vocabulary requires special attention.

We should consider that the discovery and explanation of the meaning or meanings of words and nuances in our dictionary should be done from the position of today. It requires certainly to recognize the linguistic spirit of the time, to live and walk in the footsteps of the time. Full disclosure of meanings, their explanation and illustration show that the wealth and strength of lexicon of our language is not just in the amount of different words, but their many meanings and nuances. 
It is not difficult to notice that in some words are reflected a material and spiritual reality, which relates to a policy and an assigned ideology. This happens when we have significant political changes ${ }^{1}$. The ideology is a whole system of viewpoints, ideas, notions of a class or party. In 1980s the system of Marxism-Leninism is the powerful ideological "weapon" of time. Thus, the vocabulary of 80 s had a duty to help readers (youth) to understand the world around them, the laws of its development, the changes that are made and done in our country's life. In politic speeches there are used some phrases of system: errësira fashiste, Shqipëria- fener ndricues I socializmit, Fjala e Partisë, Partia formoi luftëtarë të paepur për socialzimin, Ideologjia e huaj është helm për rininë, Himnizimi I shoqërisë komuniste, Demokraci borgjeze, Bindje ideologjike, Fjala e Partisë është ligj, Forca e ideve të marksizmit, Idetë revolucionare, Hero I punës socialiste, etc.

They are quite pronounced in politico-social vocabulary. The language of political and social life and other areas takes the standard features of this style. Everything is included in the relevant policy's stereotypes and we achieve a whole layer of ingrained phraseology2. There are included some words such as: absolutizëm, abstraksionizëm, anarkizëm, barazimtarizëm, centrizëm, fashizëm, gjeopolitikë, individualizëm, kapitalizëm, konservatorizëm, kozmopolitizëm, kubizëm, kundërrevolucion, liberalizëm, majtizëm, marksizëm, menshevizëm, militant, militarizëm, nacionalizëm, neokolonializëm, objektivizëm, oportunizëm, policentrizëm, proletariat, radikalizëm, republikëı, revizionizëm, romantizëm, socializëm, shovinizëm, tektonizëm, etc.

Nowadays, it is used the same word but with opposite connotation. These examples show how different attitudes towards content; how is modified their content, meaning and definition of their dictionary. The different explanation for the same word is conditioned by political and social attitude towards content that marks the word. Apparent differences are mainly made in politico-social vocabulary, avoiding politicizing load in explaining their content (in the dictionary of 2006). It happens as a result of revolutionary changes in the life and structure of our country.

In the Albanian lexicographical practice, developments and the changes in the content of vocabulary are presented in accordance with the scientific requirements of the time, with the level of achievement in the period when dictionaries are compiled. For a right explanation, we see and study the latest data of science, to know well life in all its manifestations, providing the essence of the notion.

A qualitative change in vocabulary is the disposal of active politico-social elements marking ideological phenomena and the old way of living or changes in their semantics. The politico-social lexicon is not only affected from linguistic factors, but also time of events and occurrences when they are used.

All these changes are taken into account by the compilers of the normative dictionary of our language. This means that the dictionary's compilation is a hard work and more responsibility. The linguist not only knows the way of the development of language, but also he is the holder himself of language of group. Therefore, he not only makes registration and explanation of the facts of language, but as a participant of the collective linguistic creativity, he does legislative norms. For this reason it is important to enter into the linguistic spirit of the period.

Levels of language system have different sensitivity to external influences. The system remains open at any time to answer new social situations.

Every enrichment or wastage in a system necessarily brings a reorganization of all its distinctive previous contrapositions.

\section{Proposed methodology}

Today the language policy aims to be more open, to reflect the words of a developed society 3 . Politico-social vocabulary of today's Albanian language has developed and continues to process its content. The base is the dialectical link with the reality of our contemporary society, as well as the concepts and today's outlook of holders of Albanian language. They want to see themselves in the same social, political, economic and cultural level with other peoples in Europe and beyond.

\footnotetext{
${ }^{1}$ Rrokaj, Sh. Issue of the Albanian language, Tirane, 2009, pp.72

2 Samara, M. "On features of political and social vocabulary today in Albanian language", PS, no.1

3 Lloshi, Xh. "Albanian language- open and dynamic language", Standard Language and Albanian Society Today, Tirane, pp.89
} 
When important social historical changes occur in society, therefore changes occur in the consciousness of people, as speakers of the language, as active members of society.

Full development of the social functions of the Albanian language in the period of socialist regime, which reflects the development of economy, science, technology, social and political life of our country, create conditions for qualitative changes in the stylistic system. Besides social history, culture and thinking on language tools, the language history traces itself, the nature and diversity of its uses. Of course, bringing of new elements, which has enriched the vocabulary, dominate over the old elements, which shows that the development of it implies obsolescence a part of it.

Changes that have been occurred in the Albanian vocabulary in recent years, are observed in the general and terminological vocabulary. They have "misled" language. Major political movements that were associated with changes in the political system, on one hand, the opening of political borders, on the other hand, have created conditions for a new life of Albanian word.

Each type of activity is also a way of view, thinking and judgment on the object, which depends on the general relationship with the object or interlocutor. This relationship is embedded socially, acquired in an environment, in a situation, event or social context, or a community. The discourser appears as the bearer of a social view, associated with cultural traditions.

After 90 s the Albanian society has been experiencing major changes, which were enable by the overthrow of the previous political system. The consequence of these changes was the free movement of people, Albanians expanded contacts with the languages and cultures of other people.

\section{Conclusions}

In this study we saw the changes in the Albanian language, reaching the following conclusions: In the period of socialist regime the Albanian language has ideological character, which reflects the development of economy, science, technology, social and political life of our country. We have different explanations of politic lexicon, that have opposite connotation. Changes that have been occurred in the Albanian vocabulary in recent years, are observed in the general and terminological vocabulary, which were enable by the overthrow of the previous political system.

\section{References}

Dictionary of Albanian language, a group of authors, 1980

Dictionary of Albanian language, a group of authors, 2006

Rrokaj, Sh. Issue of the Albanian language, Tirane, 2009

Steel, M. Standard Albanian Affairs, Tirane, 2006

Kole, J. On international words in Albanian language, Philological Studies, 1984/3, pg.100-120

Kostallari, A. In the way of drafting normative vocabulary of Albanian, Philological Studies.II, 1972, pp.80-100

Samara, M. "On features of political and social vocabulary today in Albanian language", PS, no.1

Lloshi, Xh. "Albanian language- open and dynamic language", Standard Language and Albanian Society Today, Tirane, pp.87-98

Sula, A (2012), "Albanian language, as a dynamic language", The Many Languages of Europe, A Wealth To Preserve, Tirane 